\section{Emerging research groups studying Brazilian psychiatric genetics}

\section{Grupos de pesquisa emergentes em estudos de genética psiquiátrica brasileira}

\section{Dear Editor,}

In their recent paper entitled $A$ review of psychiatric genetics research in the Brazilian population, Cordeiro et al. ${ }^{1}$ conducted an interesting review by describing the most important research groups now at work and their main findings on the Brazilian population. The authors briefly discussed relevant findings on drug addiction, alcohol dependence, pathological gambling, schizophrenia, bipolar disorder, obsessive compulsive disorder, suicidal behaviors and attention deficit hyperactivity disorder. Additionally, they argued their point of view with respect to the obstacles and challenges faced by psychiatric genetic studies considering Brazil's heterogeneous ethnicity.

Although the paper is very interesting, its authors failed to describe the methodology employed for conducting the research and, apparently, their failure in performing a systematic review resulted in they neglecting publications al ready available in the field. Our group has been studying anxiety and its endophenotypes, like personality traits as neuroticism, harm avoidance and behavioral inhibition ${ }^{2,3}$ as well as suicidal behavior in depressed patients. ${ }^{4,5}$ In brief, with respect to anxiety disorders and endophenotypes, we found no association between the serotonin transporter promoter polymorphism (5-HTTLPR) and personality traits in asymptomatic patients with panic disorder. ${ }^{3}$ We have also described preliminary evidence of the association between EFHC2 (a gene implicated in fear recognition) and harm avoidance. In this study, an intronic single nucleotide polymorphism (SNP), rs1562875, was associated with harm avoidance, accounting, alone, for over $3 \%$ of variance in this trait. This same SNP was nominally but not empirically associated with behavior inhibition and panic disorder with an odds ratio of $2.64 .^{2}$

The main results of our studies in suicidal behavior include a replication of an association between suicidal behavior and a polymorphism in the serotonin transporter gene (5-HTTLPR), demonstrating a higher risk for suicide behavior among depressed patients bearing SS or LS genotypes. ${ }^{5}$ We also performed a reanalysis of a novel 5-HTTLPR functional variant identified within the $\mathrm{L}$ allele which alters its messenger RNA production.
Even though our results did not replicate the association between functional 5-HTTLPR suicidal behavior in depressed patients who have attempted suicide, this was the first study to ever perform this kind of this analysis in a Brazilian population. ${ }^{4}$

As properly emphasized by Cordeiro et al, the Brazilian population is composed of the admixture between European, African and Native American populations, a fact which raises a number of problems when performing genetic studies. In order to avoid stratification, in our studies we use more homogenous samples like the Caucasians that live in the southern state of Rio Grande do Sul, which is an area that has recently received an important inflow of European migrants, and has suffered less African and Native American genetic influence as described in the same study.

Psychiatric genetic studies in the Brazilian population are still very much needed and, in the field of anxiety disorders and suicidal behavior, this need is even more evident. Along with the well established groups new research enterprises emerged and added relevant information to the understanding of these complex traits and behaviors. As much as ours other groups might not have their research acknowledged reinforcing the use of systematic reviews for searching manuscripts as an indispensable tool in reviewing medical literature.

Giovanni Abrahão Salum, Carolina Blaya, Gisele Gus Manfro

Anxiety Disorders Program, Hospital de Clínicas de Porto Alegre (HCPA), Universidade Federal do Rio Grande do Sul (UFRGS), Porto Alegre (RS), Brazil

Jair Segal
Post-Graduate Program in Medical Sciences: Psychiatry,
Universidade Federal do Rio Grande do Sul (UFRGS),
Porto Alegre (RS), Brazil
Hospital de Pronto Socorro de Porto Alegre,
Porto Alegre (RS), Brazil
Sandra Leistner-Segal
Hospital de Clínicas de Porto Alegre (HCPA), Serviço de
Genética Médica, Laboratório de Genética Molecular,
Porto Alegre (RS), Brazil

Revista Brasileira de Psiquiatria $\bullet$ vol $32 \cdot \mathrm{n}^{\circ} 1 \cdot \operatorname{mar} 2010 \cdot 91$ 
Disclosures

\begin{tabular}{|c|c|c|c|c|c|c|c|}
\hline $\begin{array}{l}\text { Writting group } \\
\text { member }\end{array}$ & Employment & $\begin{array}{l}\text { Research } \\
\text { grant }^{1}\end{array}$ & $\begin{array}{c}\text { Other research grant } \\
\text { or medical continuous } \\
\text { education }^{2}\end{array}$ & $\begin{array}{l}\text { Speaker's } \\
\text { honoraria }\end{array}$ & $\begin{array}{c}\text { Ownership } \\
\text { interest }\end{array}$ & $\begin{array}{l}\text { Consultant/ } \\
\text { Advisory } \\
\text { board }\end{array}$ & Other ${ }^{3}$ \\
\hline $\begin{array}{l}\text { Giovanni } \\
\text { Abrahão Salum }\end{array}$ & HCPA/UFRGS & $\begin{array}{c}\text { CNPq } \\
\text { FIPE/HCPA }\end{array}$ & - & - & - & - & - \\
\hline Carolina Blaya & HCPA/UFRGS & $\begin{array}{c}\text { CAPES } \\
\text { FIPE/HCPA }\end{array}$ & - & Eli-Lilly* & - & - & - \\
\hline $\begin{array}{l}\text { Gisele Gus } \\
\text { Manfro }\end{array}$ & HCPA/UFRGS & $\begin{array}{c}\text { CNPq } \\
\text { FIPE/HCPA }\end{array}$ & - & $\begin{array}{c}\text { Eli-Lilly* } \\
\text { Boehringer* }\end{array}$ & - & - & Roche* \\
\hline Jair Segal & HCPA/UFRGS & $\begin{array}{c}\text { CNPq } \\
\text { FIPE/HCPA }\end{array}$ & - & - & - & - & - \\
\hline $\begin{array}{l}\text { Sandra Leistner- } \\
\text { Segal }\end{array}$ & HCPA/UFRGS & $\begin{array}{c}\text { CNPq } \\
\text { FIPE/HCPA }\end{array}$ & - & - & - & - & - \\
\hline
\end{tabular}

* Modest

** Significant

*** Significant. Amounts given to the author's institution or to a colleague for research in which the author has participation, not directly to the author. Note: HCPA = Hospital de Clínicas de Porto Alegre; FIPE/HCPA = Fundo de Incentivo à Pesquisa do Hospital de Clínicas de Porto Alegre; UFRGS = Universidade Federal do Rio Grande do Sul; CNPq = Conselho Nacional de Desenvolvimento Científico e Tecnológico; CAPES = Coordenação de Aperfeiçoamento de Pessoal de Nível Superior.

For more information, see Instructions for authors.

References

1. Cordeiro Q, Souza BR, Correa H, Guindalini C, Hutz MH, Vallada H, RomanoSilva MA. A review of psychiatric genetics research in the Brazilian population. Rev Bras Psiquiatr. 2009;31(2):154-62.

2. Blaya C, Moorjani P, Salum GA, Goncalves L, Weiss LA, Leistner-Segal S, Manfro GG, Smoller JW. Preliminary evidence of association between EFHC2, a gene implicated in fear recognition, and harm avoidance. Neurosci Lett. 2009;452(1):84-6.

3. Wachleski C, Blaya C, Salum GA, Vargas V, Leistner-Segal S, Manfro GG. Lack of association between the serotonin transporter promoter polymorphism
(5-HTTLPR) and personality traits in asymptomatic patients with panic disorder. Neurosci Lett. 2008;431(2):173-8.

4. Segal J, Schenkel LC, Oliveira MH, Salum GA, Bau CH, Manfro GG, LeistnerSegal S. Novel allelic variants in the human serotonin transporter gene linked polymorphism (5-HTTLPR) among depressed patients with suicide attempt. Neurosci Lett. 2009;451(1):79-82.

5. Segal J, Pujol C, Birck A, Gus Manfro G, Leistner-Segal S. Association between suicide attempts in south Brazilian depressed patients with the serotonin transporter polymorphism. Psychiatry Res. 2006;143(2-3):289-91.

\section{Population stratification in European South-American subjects and its importance to psychiatric genetics research in Brazil}

\section{Estratificação populacional em sul-americanos de origem européia e sua importância para a pesquisa genética psiquiátrica no Brasil}

\section{Dear Editors,}

It is really very exciting to know that another Brazilian group is working with molecular investigation in the field of psychiatric genetics. ${ }^{1}$ When we decided to write a paper about the particularities, advantages and difficulties of conducting psychiatric genetic studies in the Brazilian population, we were aware of the possible biases of a narrative review. ${ }^{2}$ However, that kind of approach seemed to be a more appropriate method in terms of our proposal because we believe that, by describing the history, development, and management of psychiatric genetic investigations in Brazil, we would be contemplating several contextual, cultural and political aspects and integrating different and independent fields of research in order to acquire a wider and multidisciplinary view of the subject at hand.

There is also another important point raised by Salum et al. ${ }^{1}$ that needs to be addressed. Differently from what they claim, the use of "more homogenous samples like the Caucasians" does not "avoid stratification" in association studies on complex disorders such as neuropsychiatric disorders. ${ }^{2}$

Nowadays, it is well known that even when studying samples from a specific continental population such as the European, ethnic stratification can produce false associations at markers whose frequency differs across subpopulations. ${ }^{3}$ For example, in a recent whole genome association study of rheumatoid arthritis in European Americans, markers in the LCT and IRF4 genes could have been falsely implicated as being associated with the disease had no control method been applied to for the population's 